\title{
Training for Medical Tourism in Iran
}

\section{Zahra Danial', Abbas Abbaspour ${ }^{*}$, Hamid Rahimian', Nasrin Shaarbafchi Zadeh², Mostafa Niknami'}

${ }^{1}$ Faculty of Psychology and Educational Sciences, Allameh Tabataba'i University, Tehran, Iran

${ }^{2}$ Health Management and Economics Research Center, Isfahan University of Medical Sciences, Isfahan, Iran

Corresponding Author: Abbas Abbaspour, PhD, Associate Professor, Faculty of Psychology and Educational Sciences, Allameh Tabataba'i University, Tehran, Iran. Tel: +982188053766, Email: abbaspour1386@gmail.com

Received July 5, 2017; Accepted August 1, 2017; Online Published August 26, 2017

\begin{abstract}
Introduction: Today, medical tourism is becoming popularized through the upgrading of quality standards essential to providing appropriate and high quality services to those in need. Training is an essential factor in improving the current standards. Medical tourism can provide state-of-the-art treatment for patients.

Methods: This study is a narrative review of studies aimed at investigating the importance of training in medical tourism and to address the question of whether training in the development of medical tourism and attracting medical tourists is feasible.

Results: Medical tourism can provide state-of-the-art treatment for patients. Experts in the field of medical tourism can help a tourist select his/her destination country. The development of medical tourism in Iran means providing high-tech facilities and personnel who are highly-trained in medical tourism, familiarization with the culture of medical tourists, the cooperation of stakeholders, advertisement of medical tourism, and so on.

Conclusion: To develop medical tourism in Iran, in addition to the necessary equipment, the necessary training should also be provided, such as an introduction to medical tourism and the medical tourist and knowledge of the rules and regulations of medical tourism. Participants in training should be stakeholders in both the medical and the tourism sectors. It is necessary to design a training model for Iranian medical tourism.

Keywords: Training, Medical Tourism, Staff Development, Iran
\end{abstract}

Citation: Danial Z, Abbaspour A, Rahimian H, Shaarbafchi Zadeh N, Niknami M. Training for medical tourism in Iran. Int J Travel Med Glob Health. 2017;5(3):77-83. doi:10.15171/ijtmgh.2017.17.

\section{Introduction}

The globalization of health care has led to a new form of tourism commonly known as health, or medical, tourism. Medical tourism has grown rapidly, and many countries are currently planning for the incorporation of this sector. ${ }^{1-3}$ Medical tourism is a situation wherein tourists seek alternative medical treatment opportunities in other countries. ${ }^{4-6}$ According to the World Tourism Organization (WTO), medical tourism is the use of services that lead to improved or increased health through medical interventions in a place outside the place of residence of an individual that lasts more than 24 hours. ${ }^{4,7,8}$ The concept of medical tourism was not commonly contemplated until recently. In fact, it was difficult to imagine a connection between the two very different sections of international travel and medical care. Medical tourists leave their country of origin to obtain effective medical services (high quality and low prices). ${ }^{9}$ This industry has grown rapidly over the last two decades, and due to high foreign exchange earnings in this industry, many countries are actively planning to enter this field..$^{10}$ In a strategic and competitive situation, development needs to be strengthened and it must also strengthen its supporting industries. ${ }^{11}$

Formerly, the trend of medical tourism was the travel of wealthy people from less developed countries to developed countries to receive medical care. ${ }^{12,13}$ Medical tourism currently generates $\$ 60$ billion a year globally, and the number of countries offering advanced medical care for foreign tourists is growing. ${ }^{14,15}$ Also, international trade in medical services has a very high economic potential for the global economy; thus, medical tourism is emerging as a particularly lucrative sector for developing countries. Investing in this sector results in a series of rising incomes, improving services, generating foreign exchange earnings, and the creation of a more favorable balance between trade and tourism. ${ }^{16-18}$

Today, human life is accompanied by amazing changes. Organizations must be prepared to face these massive changes. The purpose of this preparation should not be the preparation of technology and equipment; rather, it must be the expert staff,

Copyright $\odot 2017$ The Author(s). This is an open-access article distributed under the terms of the Creative Commons Attribution License (http:// creativecommons.org/licenses/by/4.0), which permits unrestricted use, distribution, and reproduction in any medium, provided the original work is properly cited. 
i.e. an important, valuable capital. A successful organization pays more attention to human resources, which can be the key to its success. ${ }^{19}$ Training is considered paramount to medical tourism, because it reduces medical errors and increases satisfaction among medical tourists. ${ }^{20}$ Training is a tool for improving the quality of performance, solving managerial problems, empowering the human resources of an organization, and increasing efficiency. ${ }^{19,21}$ A literature review showed that to date no study has examined the parameters of medical tourism and educational requirements. Training programs should be created for the effective performance of relevant people who have specific roles and responsibilities in the tourism and healthcare sectors. ${ }^{22}$

Specialized factors play an important role in competition. Some of these factors are trained personnel, appropriate infrastructures, security, education, and proper research policies inherent to the competitive power of an industry. ${ }^{23}$ Trained expert individuals are influential in the economic, social, and cultural sectors relating to medical tourism. The lack of knowledge and suitable skills will have a negative impact. Employees at every level need to acquire new knowledge and skills to better do their work. ${ }^{24}$ Today, the importance of tourism in terms of economics and job creation is such that it can be considered the driving economic force of any country. Tourism has many advantages and can be an important source of employment. ${ }^{25}$

Today, medical tourism and the attraction of foreign patients have been seriously addressed by professionals and politicians. ${ }^{26}$ Given its great value, many private sector investors tend to invest in medical tourism. ${ }^{5,27}$ Training as a factor in improving employee performance can be the basis for providing standards. ${ }^{28}$ There are challenges and obstacles that hinder medical tourism. The first challenge is linguistic differences. When practitioners cannot properly communicate with a patient, medical errors may arise, and this challenge alone is enough to affect the satisfaction of tourists. A second challenge is that of cultural differences which could obstruct the development of guidelines for international quality standards. ${ }^{29} \mathrm{~A}$ third challenge is religious differences. This challenge can sometimes influence treatment. Several studies have reported a reduction in errors by trained staff and increased effectiveness and productivity, which have positive impacts on trade. ${ }^{30,31}$ With the increased amount and functionality of new information, technologies have also gradually changed the basic assumptions about the role of ICT in organizations. ${ }^{32}$ Therefore, other issues that could lead to the development of tourism include ICT training for restaurant and hotel staff. This skill is the first step towards a sustainable development culture, especially for restaurant managers. ${ }^{33-35}$ Training in all sectors, such as marketing, is also a factor in the development of service quality. ${ }^{36}$ Because of the importance of medical tourism to a country's development, this paper surveyed the role of training in expanding medical tourism in Iran.

\section{Methods}

This study was designed as a narrative review of studies dated from February 2007 to June 2017 and aimed to investigate the importance of training in medical tourism in Iran. Library resources were reviewed, and reliable databases, i.e. Medline, ISI Web of Science, EMBASE, Scopus, PubMed, Ebsco, and Emerald were searched extensively for information on medical tourism in Iran. The search strategy was based on the following keywords:

"Medical Tourism", "Medical Travel", "Health Tourism", "Curative Tourism", "Education", “Training”, "Learning”, “Training Tourism", "Learning Tourism".

To find additional articles or unpublished data, relevant study lists were searched by hand. The available studies were summarized and their results were reported. Four authors assessed the titles and abstracts of articles found through these search methods using predefined inclusion and exclusion criteria. Disagreements were resolved through discussion. Where a resolution was not reached, other authors were consulted. The authors extracted data using an extraction sheet, and disagreements were resolved in a group meeting.

\section{Results}

The results of this study indicate that training has a positive impact on the improvement of medical tourism. Moreover, training courses for medical tourism professionals is one of the indicators evaluated in medical centers. ${ }^{37}$ The neglect of medical tourism trainees is a deterrent to the growth of medical tourism. ${ }^{38}$ Thus, training increases satisfaction among staff and medical tourists. Investing in knowledge, skills, and human capital influences development and the competitive medical tourism market, ${ }^{39-41}$ and acquiring skills in innovation and creativity leads to business success and development. ${ }^{42}$ Training stakeholders' medical tourism, in addition to acquiring skills of using modern technologies, they will be better and faster perceived customers' expectations. ${ }^{43-45}$ Such training should be followed by the establishment of international quality standards for the development of travel medicine, including linguistic and cultural education. ${ }^{20,24,46}$

Iran is an Islamic country, and it is necessary for Islamic countries to have cultural competence in providing clinical services to Muslim medical tourists. ${ }^{47}$ Another challenge of medical tourism is the lack of proficiency in English or other foreign languages. ${ }^{48}$ In medical tourism, the health and education sectors focus their needs on education and their expectations on the relevant ministries and organizations of health, tourism, and education. There are several challenges to medical tourism, one of which is tourism and depends on a proper organizational structure, programming, and a trained workforce. ${ }^{5}$

Another necessity that subjects in this study identified was that all stakeholders from the public and private sectors must learn to improve their knowledge and qualifications and raise public awareness of laws relevant to medical tourism. Therefore, it is important to consider the possibly powerful potential of medical tourism for the development of a global health education system. ${ }^{49}$ Medical tourism recruitment factors include professional human resources from hospitals who have international work records, training courses, being 
fluent in English, and promoting all aspects of professional human resources. ${ }^{50,51}$ The hospitals are suitable for some standards (access to and continuity of treatment, patient evaluation, anesthetic care and drug management), but only adequate for others (patient and family rights, patient care, staff education, and patient education). ${ }^{52}$ Researchers emphasizing training human resources in medical tourism are listed in Table 1.

\section{Discussion}

It can be argued that training to increase the efficiency and productivity of employees is the most comprehensive method. In fact, investing in training promotes the performance of individuals in the organization. ${ }^{53}$ Training must be appropriate to the actual business and on the demand of the employers. ${ }^{54}$ Also, the pace of global change causes the existing educational needs to change..$^{55}$ The development of tourism increases the living standards of local communities, but the attraction of tourists requires several solutions. One basic strategy is the educational planning for the development of human resources. ${ }^{56}$ Medical tourism as a form of tourism is not separate from these issues. Studies conducted to date in the field of medical tourism have focused on the relationship between the fields of economics, health, and politics. ${ }^{57}$

Despite the importance of training in medical tourism and studies that consider the need training on medical tourism issues as necessary to improve employees' skills and knowledge and increase their and the public's awareness of medical issues,

Table 1. Medical Tourism Education Research in the World

\begin{tabular}{|c|c|c|c|c|}
\hline Row & Researcher & Year & Research Goals & Research Findings \\
\hline 1 & $\begin{array}{l}\text { Ganguli and } \\
\text { Ebrahim }^{39}\end{array}$ & 2017 & $\begin{array}{l}\text { Analyze and identify the factors affecting the } \\
\text { competitive market of medical tourism }\end{array}$ & $\begin{array}{l}\text { Investing in knowledge, skills, and human capital influences the } \\
\text { development of competitive market medical tourism. }\end{array}$ \\
\hline 2 & Page et $\mathrm{al}^{42}$ & 2017 & $\begin{array}{l}\text { Create research knowledge through training in tourism } \\
\text { entrepreneurs }\end{array}$ & $\begin{array}{l}\text { Acquiring innovation and creativity skills will lead to business } \\
\text { success and development. }\end{array}$ \\
\hline 3 & Rahman et $a^{61}$ & 2017 & The formation of future Islamic tourism & Infrastructures, including cultural education, should be created. \\
\hline 4 & Wang ${ }^{45}$ & 2017 & $\begin{array}{l}\text { Determine the effect of medical tourism on } \\
\text { expectations, satisfaction, and behavior of medical } \\
\text { tourists }\end{array}$ & $\begin{array}{l}\text { Providers of medical tourism services not only should acquire } \\
\text { skills in the use of modern technologies, but also be aware of } \\
\text { the customer's perceptions and expectations. }\end{array}$ \\
\hline 5 & Savasan et $\mathrm{al}^{22}$ & 2016 & $\begin{array}{l}\text { Analysis Training needs Stakeholders in Medical } \\
\text { Tourism }\end{array}$ & $\begin{array}{l}\text { The education sector must be a part of the relations of the cycle } \\
\text { surrounding medical tourism. }\end{array}$ \\
\hline 6 & Kácha et $\mathrm{al}^{20}$ & 2016 & $\begin{array}{l}\text { Determine key factors in establishing travel medical } \\
\text { standards }\end{array}$ & $\begin{array}{l}\text { An approach is provided to establishing international quality } \\
\text { standards for the development of travel medicine, including } \\
\text { linguistic and cultural education. }\end{array}$ \\
\hline 7 & Chang et $\mathrm{al}^{21}$ & 2016 & $\begin{array}{l}\text { Determine the effective factors in the attraction of } \\
\text { medical tourists }\end{array}$ & $\begin{array}{l}\text { Medical centers can help the marketing and management } \\
\text { of medical tourism through the development of educational } \\
\text { programs. }\end{array}$ \\
\hline 8 & Nguyen $^{41}$ & 2016 & $\begin{array}{l}\text { Identify the factors influencing excellence and } \\
\text { impression of medical tourism }\end{array}$ & $\begin{array}{l}\text { The satisfaction of medical tourists can be increased by } \\
\text { providing high quality services. }\end{array}$ \\
\hline 9 & Zailani et $\mathrm{al}^{47}$ & 2016 & $\begin{array}{l}\text { Predict the satisfaction of Muslim medical tourists } \\
\text { from Islamic hospitals }\end{array}$ & $\begin{array}{l}\text { Cultural competence is essential in providing clinical services to } \\
\text { Muslim medical tourists. }\end{array}$ \\
\hline 10 & $\begin{array}{l}\text { Fetscherin and } \\
\text { Stephano }^{37}\end{array}$ & 2016 & $\begin{array}{l}\text { Assess performance; destination as a factor effective in } \\
\text { medical tourism }\end{array}$ & $\begin{array}{l}\text { Training courses for medical tourism professionals is one of the } \\
\text { indicators evaluated. }\end{array}$ \\
\hline 11 & da Borralha et $\mathrm{al}^{33}$ & 2016 & $\begin{array}{l}\text { Identify effective variables in employee hospitality } \\
\text { performance }\end{array}$ & $\begin{array}{l}\text { Human resource management policies should be concentrated } \\
\text { to educate staff. }\end{array}$ \\
\hline 12 & Khan et $\mathrm{al}^{43}$ & 2016 & $\begin{array}{l}\text { Investigate the dangers, travel motives, cognitive and } \\
\text { emotional images of medical tourists }\end{array}$ & $\begin{array}{l}\text { Barriers to the development of medical tourism are an } \\
\text { insufficient infrastructure, lack of trained forces, and the } \\
\text { inaccessibility of tourism and health destinations. }\end{array}$ \\
\hline 13 & $\begin{array}{l}\text { Taghvaei and } \\
\text { Goodarzi } i^{60}\end{array}$ & 2016 & $\begin{array}{l}\text { The development and prioritization of strategies for } \\
\text { the development of medical tourism }\end{array}$ & $\begin{array}{l}\text { These strategies are proposed: introduction of medical and } \\
\text { tourism capabilities through electronic and non-electronic } \\
\text { advertising; provision of training courses for the promotion } \\
\text { professional human resource skills. }\end{array}$ \\
\hline 14 & Vitthal et $\mathrm{al}^{6}$ & 2015 & $\begin{array}{l}\text { Identify the key competitive benefits of medical } \\
\text { tourism }\end{array}$ & $\begin{array}{l}\text { The competitive advantages include low cost, reputation in } \\
\text { advanced health care, quality of services, and diversity of } \\
\text { existing tourism destinations. }\end{array}$ \\
\hline 15 & Crooks et $\mathrm{al}^{7}$ & 2015 & $\begin{array}{l}\text { Identify the impact of medical tourism on medical staff } \\
\text { immigration }\end{array}$ & $\begin{array}{l}\text { Policy makers in destination countries prevent the negative } \\
\text { effects of medical tourism by ensuring training for health } \\
\text { workers with the aim of promoting the tourism sector, and this } \\
\text { will support the health needs of the domestic population. }\end{array}$ \\
\hline 16 & $\begin{array}{l}\text { Maboodi and } \\
\text { Hakimi }^{24}\end{array}$ & 2015 & Investigate the determinants of medical tourism & $\begin{array}{l}\text { Experienced and trained staff, quality of medical services, the } \\
\text { existence of medical equipment and advanced technology are } \\
\text { main drivers in medical tourism. }\end{array}$ \\
\hline 17 & Fisher and Sood ${ }^{26}$ & 2014 & $\begin{array}{l}\text { Investigate the experiences of medical tourists and } \\
\text { effective variables in the growth of medical tourism }\end{array}$ & $\begin{array}{l}\text { Variables such as cost, time, trained people, availability, } \\
\text { insurance coverage, past international travels, visas, reputation, } \\
\text { and population growth-enhancing medical tourism are effective. }\end{array}$ \\
\hline 18 & Dredge et $\mathrm{al}^{31}$ & 2014 & $\begin{array}{l}\text { The formation of factors and hosting management } \\
\text { programs }\end{array}$ & $\begin{array}{l}\text { Educational administrators and planners should consider issues } \\
\text { such as regional and global changes and challenges ahead. }\end{array}$ \\
\hline
\end{tabular}




\section{Table 1. Continued}

\begin{tabular}{|c|c|c|c|}
\hline 19 & Sharma $^{14}$ & 2017 & $\begin{array}{l}\text { Study medical tourism and its impact on social and } \\
\text { economic development }\end{array}$ \\
\hline 20 & $\begin{array}{l}\text { Morovati } \\
\text { Sharifabadi } \\
\text { and Asadian } \\
\text { Ardakani }^{40}\end{array}$ & 2014 & $\begin{array}{l}\text { Identify and rank marketing mix elements for the } \\
\text { development of medical tourism marketing }\end{array}$ \\
\hline 21 & $\begin{array}{l}\text { Hadizadeh } \\
\text { Moghadam et } \mathrm{al}^{46}\end{array}$ & 2013 & $\begin{array}{l}\text { Identify the most important motivating factors for } \\
\text { travel abroad }\end{array}$ \\
\hline 22 & Hana et $\mathrm{al}^{65}$ & 2013 & $\begin{array}{l}\text { Identify the hospital and hotel benefits in medical } \\
\text { tourism }\end{array}$ \\
\hline 23 & Kelley ${ }^{50}$ & 2013 & Identify the main drivers of medical tourism \\
\hline 24 & Lunt et $\mathrm{l}^{58}$ & 2013 & Study the consequences of medical tourism \\
\hline 25 & Izadi et al ${ }^{5}$ & 2014 & $\begin{array}{l}\text { Identify obstacles to the development of health } \\
\text { tourism }\end{array}$ \\
\hline
\end{tabular}

Tourism increases job opportunities, exchange of earnings, and contributes to the improvement of living standards as well as the development of infrastructures and a quality education system.

Effective factors in the growth of medical tourism include training and skills for staff, use of specialists, price of services, type and quality of services, and equipment and facilities.

Through training in foreign languages and cultural issues, the patient easily communicates with the surrounding environment and professionals.

The presence of trained people in the hotel is effective in satisfying and gaining the trust of medical tourists.

The main drivers of medical tourism are advanced technology, quality of care, facilitating services, low cost of services

Effective role of government, professionals and stakeholders of medical tourism and the relations between them

The main challenges of health tourism in Iran and tourism development depends on factors such as proper organizational structure, programming, and a trained workforce.

Industry professionals must work in a variety of ways, such as the use of skilled and trained staff and advertisements to attract medical tourists and use information and feedback to develop marketing strategies.

Some of the most important factors in the development of the health sector is research, training health tourism professionals and providers of health care, medical technology, equipment for hospitals and health centers, and tourism.

This study emphasizes the link between the university's education system and the management fields of the tourism industry. $28 \begin{aligned} & \text { Heidari Chianeh } \\ & \text { et al }^{63}\end{aligned} 2012 \begin{aligned} & \text { Determine the abilities, weaknesses, threats and } \\ & \text { challenges of tourism education in the academic } \\ & \text { system }\end{aligned}$

29 Jabbari ${ }^{48}$ Kesar and Rimac ${ }^{38} 2011$

Identify the positive and negative parts of Iran's medical tourism industry

Study the development of medical tourism in developing countries

31 Johnston et $\mathrm{al}^{49}$

2010 Investigate the impact of medical tourism on destination countries

Develop an understanding of hospitals' ability to

32 Nasiripour and Salmani ${ }^{51}$

attract foreign patients based on global criteria of competition in medical tourism and provide a solution for the development of therapeutic tourism

Evaluate the capabilities of selected hospitals of the

33 Khodayari ${ }^{52}$

University of Medical Sciences in attracting medical tourists

Investigate the factors influencing the developmen

Sadr Momtaz and

Agharahimi $^{64}$

2011

me views of hospital managers
One of the challenges is a lack of proficiency in English or other foreign languages.

The neglect of medical tourism trainees is a deterrent to the growth of medical tourism.

It is important to pay attention to the powerful potential of medical tourism for the development of a global health education system.

Medical tourism recruitment factors include the professional human resources of hospitals with international work records, training courses, fluency in English, and the promotion of all aspects of professional human resources.

The hospitals are suitable for some standards (access to and continuity of treatment, patient evaluation, anesthetic care and drug management), and adequate for some standards (patient and family rights, patient care, and staff and patient education).

After the development of a public infrastructure, human resource development is provided through skills training, in which a comprehensive and coordinated plan should be developed. no source for principled and program-based training services related to medical tourism has been named in studies. ${ }^{22}$ The findings of the current study determined the important role of governments in developing medical tourism facilities and revenues, state-funded and private education systems which must pay specific attention to this subject, and training opportunities on this subject provided for all stakeholders. The government should develop rules and regulations that allow procedures to be more easily accomplished for medical tourists, the rules and regulations relevant to medical tourism should be understood and implemented both public and private sectors. ${ }^{22,58}$ Researchers are emphasizing e-learning and telemedicine at hospitals and health centers in medical tourism $\mathrm{m}^{59}$; providing national and international training courses to enhance the skills of professional human resources globally and recruiting trained specialists; and using information and communication technology were identified as the top priorities. ${ }^{60}$ However, despite academic disciplines in education, which is highlighted as a distinct part of the health sector, education has not been properly adopted. ${ }^{22}$

Studies in the field of medical tourism training are few. This may be due to the lack of other infrastructures, such as laws and regulations, equipment, and other facilities for medical tourism, ${ }^{20,21,39}$ and the lack of attention to training, because it is 
qualitative ${ }^{56}$ Studies have a positive effect on the development of medical tourism by influencing the training of staff, but most studies show a lack of training among staff members. Most of the data shows that training is not academic; it is held periodically, and participants will be given a certificate. ${ }^{37}$ Savasan et $\mathrm{al}^{22}$ identified the stakeholders of medical tourism and that each group should be provided training based on expert opinions.

In a study on the purpose of Islamic tourism, the issue of cultural and religious differences was proposed ${ }^{47}$ Other studies emphasized the importance of training in increasing the efficiency and effectiveness of medical tourism programs. ${ }^{42,61}$ The overall results of studies suggest that medical tourism training should be developed. .11,17,49 $^{-1}$

\section{Conclusion}

The prosperity of the medical tourism industry in Iran can have many benefits to economic, political, social, and cultural development. One of the most important factors in the growth of medical tourism is training, because having a trained and experienced adviser in the field of medical tourism can help tourists choose their destination country. Consequently, to develop medical tourism in Iran, not only equipment, but also the necessary training should be provided, including an introduction to medical tourism and the medical tourist, the medical histories of medical tourists, the association of staff with medical tourism, and knowledge of the rules and regulations of medical tourism for stakeholders in two parts of medicine (hospitals and health centers) and the tourism sector, e.g., transportation agencies, residences, and restaurants. A training model must be designed for Iranian medical tourism.

\section{Authors' Contributions}

All authors contributed equally to this study.

\section{Conflict of Interest Disclosures}

The authors declare they have no conflicts of interest.

\section{Ethical Approval}

Not applicable.

\section{Funding/Support}

None.

\section{Acknowledgments}

This paper has been extracted from a $\mathrm{PhD}$ dissertation. The authors would like to warmly thank all of the Delphi panel members who helped us to accomplish and Professor Mohammad Hossein Kalantar Motamedi for his assistance in this study.

\section{References}

1. Ayoubian A, Tourani S, Hashemi Dehaghi Z. Medical Tourism Attraction of Tehran Hospitals. Int J Travel Med Glob Health. 2013;1(3):95-98.

2. Popescu A. Considerations on the development of medical tourism at world level and in Romania. Scientific Papers Series-

\section{Review Highlights}

\section{What Is Already Known?}

Training is very important in medical tourism, because it reduces medical errors and increases the satisfaction of medical tourists. Training is a notable approach for improving the quality of performance, solving managerial problems, empowering human resources of the organization, and increasing efficiency. To the best of the authors' knowledge, no previous study has examined the parameters of medical tourism and educational requirements in Iran.

\section{What This Study Adds?}

Effectiveness and productivity in medical tourism rely on systematic and organized connections with other agents and sections such as those of health, education, politics, and economy. Training programs should be created for the effective performance of relevant professionals who have specific roles and responsibilities in medical tourism. One of the most important factors in the growth of medical tourism is training. To develop medical tourism in Iran, not only equipment, but also the necessary training should be provided.

Management, Economic Engineering in Agriculture and Rural Development. 2015;15(3):241-52

3. Ruggeri K, Zalis L, Meurice CR, et al. Evidence on global medical travel. Bull World Health Organ. 2015;93(11):785-789. doi:10.2471/blt.14.146027.

4. Connell J, ed. Mind and Matter: Health Tourism or Cosmetic Surgery? Medical tourism. Wallingford: CABI; 2011:23-41. doi: 10.1079/9781845936600.0023.

5. Izadi M, Saadat SH, Ayoubian A, Hashemi Dehaghi Z, Karbasi $M R$, Jalali AR. Health tourism in Iran; identifying obstacles for Development of This Industry. Int J Travel Med Glob Health. 2013;1(3):89-94.

6. Vitthal PC, Subhash AR, Sharma BR, Ramachandran M. Emerging trends and future prospects of medical Tourism in India. J Pharm Sci Res. 2015;7(5):248-51.

7. Crooks VA, Li N, Snyder J, et al. "You don't want to lose that trust that you've built with this patient...": (dis)trust, medical tourism, and the Canadian family physician-patient relationship. BMC Fam Pract. 2015;16:25. doi:10.1186/s12875-015-0245-6.

8. Saadatnia F, Mehregan MR. Determining and prioritizing factors affecting to increase customers attraction of medical tourism from the perspective of Arabic countries (case Study: Iran-Mashhad Razavi hospital). Int J Mark Stud. 2014;6(3):155. doi:10.5539/ijms. v6n3p155.

9. Wong KM, Velasamy $\mathrm{P}$, Tengku Arshad TN. Medical Tourism Destination SWOT Analysis: A Case Study of Malaysia, Thailand, Singapore and India. SHS Web of Conferences; 2014. https:// www.shs-conferences.org/articles/shsconf/pdf/2014/09/ shsconf_4ictr2014_01037.pdf.

10. Asemaneh Z, Emamgholipour S. The status of successful Asian countries in health tourism (review of the situation in Iran). Proceedings of the first National Conference on Geography, Tourism, Natural Resources and Sustainable Development; Tehran, Tehran University; 2014.

11. Delgoshaee B, Jabbari A, Farzin M, Sherebafchizade N, Tabibi S. Current status of medical tourism: case study of Iran. Quarterly of Payesh. 2012;2(1):171-179. [Persian].

12. Jaapar M, Musa G, Moghavvemi S, Saub R. Dental tourism: examining tourist profiles, motivation and satisfaction. Tour 
Manag. 2017;61:538-552. doi:10.1016/j.tourman.2017.02.023.

13. Tourani S, Tabibi SJ, Tofighi S, Shaarbafchi ZN. International trade in health services in the selected countries of Asean Region, challenges and opportunities. Health Information Management. 2011;8(4):453-468. [Persian].

14. Sharma V, Sharma V. Patient satisfaction and brand loyalty in health-care organizations in India. J Asia Bus Stud. 2017;11(1):7387. doi:10.1108/JABS-09-2015-0157.

15. Shaarbafchi-Zadeh N, Azami S, Bastani P. Opportunities and challenges against cross border supply of health services in Iranian health sector: a qualitative approach. Razi J Med Sci. 2012;19(100):1-11. [Persian].

16. Heung VCS, Kucukusta D, Song H. Medical tourism development in Hong Kong: An assessment of the barriers. Tour Manag. 2011;32(5):995-1005. doi:10.1016/j.tourman.2010.08.012.

17. Izadi M, Hoseinpourfard M, Ayoubian A, Karbasi M, Jahangiri $M$, Jalali A. Survey to the implementation of Islamic standards in the hospitals of Iran for attraction of muslim medical tourists. Int J Travel Med Glob Health. 2014;1(3):99-102.

18. Sultana S, Haque A, Momen A, Yasmin F. Factors affecting the attractiveness of medical tourism destination: an empirical study on India- review article. Iran J Public Health. 2014;43(7):867-876.

19. Abbaspour A, Badri M. The relationship between psychological empowerment and effective factors of productivity of human resources. Management Studies in Developement and Evolusion. 2016;24(79):73-100. [Persian].

20. Kacha O, Kovacs BE, McCarthy C, et al. An approach to establishing international quality standards for medical travel. Front Public Health. 2016;4:29. doi:10.3389/fpubh.2016.00029.

21. Chang IC, Chou P-C, Yeh RK-J, Tseng H-T. Factors influencing Chinese tourists' intentions to use the Taiwan Medical Travel App. Telematics and Informatics. 2016;33(2):401-409. doi:10.1016/j. tele.2015.09.007.

22. Savasan A, Uzunboylu H, Tuncel E. Training in medical tourism, a necessity or a perspective? a needs analysis of stakeholders on training issues in medical tourism. Int J Edu Sci. 2016;15(1,2):225233.

23. Yavari K, Ghasemi A, Shahhosseini S, Zeraati M, Mirmohammadi $\mathrm{H}$. Tourism cluster: a new approach in expanding tourism industry. Tehran: The Institute for Trade Studies and Research; 2006. [Persian].

24. Maboodi MT, Hakimi H. Determinant Factors on Medical Tourism (Case Study: Iran). Tourism Planning and Development. 2016;4(15):80-106. [Persian].

25. Sabrkesh A, Mazinani H, Normohhamadi $H$. Training and development of human resources in organization. Management Studies on Entrepreneurship Education. 2012;4(24):107-124. [Persian].

26. Fisher $\mathrm{C}$, Sood $\mathrm{K}$. What is driving the growth in medical tourism? Health Mark Q. 2014;31(3):246-262. doi:10.1080/07359683.20 14.936293

27. Asadi MM, Heidari M, Asadian F. Forecasting religious tourism demand using artificial intelligence case study: Mashhad city. International Journal of Humanities and Cultural Studies. 2016;special issue:1597-617.

28. Khorasani A, Abbaspour A, Vafayizadeh M. Studying the effective factors on transfer of training through in-service trainings of university of Tehran's non-faculty staff: based on Holton's model. Journal of Training and Development of Human Resources. 2015;2(5):1-25. [Persian].

29. Esiyok B, Çakar M, Kurtulmuşoğlu FB. The effect of cultural distance on medical tourism. Journal of Destination Marketing \& Management. 2017;6(1):66-75. doi: 10.1016/j.jdmm.2016.03.001.

30. Downing BT, Tillery $\mathrm{KH}$. Professional Training for Community Interpreters. A Report on Models of Interpreter Training and the Value of Training. https://eric.ed.gov/?id=ED356640. Published 1992.

31. Dredge D, Airey D, Gross MJ. The Routledge Handbook of Tourism and Hospitality Education. Abingdon: Routledge; 2014

32. Farhanghi AA, Abbaspour A, Ghassemi RA. Examining the structural relationships of new communication and information technologies, organizational structure and firm performance: an analysis of consultant engineers firms (CEF) in Iran. World App Sci J. 2012;20(4):605-614.

33. da Borralha S, de Jesus SN, Pinto P, Viseu J. Job Satisfaction in hotel employees: a systematic review of the literature. Journal of Spatial and Organizational Dynamics. 2016;4(1):4-20.

34. Lai PY, Lee JS, Lim YX, Yeoh RG. The linkage between training and development and co-worker support towards emplayees' engagement in hotel industry. Malaysia: Universiti Tunku Abdul Rahman; 2014.

35. Torabi Farsani N, Sadeghi R, Shafiei Z, Shahzamani Sichani A Measurement of satisfaction with ICT services implementation and innovation in restaurants (case study: Isfahan, Iran). J Travel Tour Mark. 2016;33(2):250-262. doi:10.1080/10548408.2015.10 50540.

36. Kheiri J, Nasihatkon B. The effects of rural tourism on sustainable livelihoods (case study: Lavij rural, Iran). Modern Applied Science. 2016;10:10. doi:10.5539/mas.v10n10p10.

37. Fetscherin M, Stephano R-M. The medical tourism index: Scale development and validation. Tour Manag. 2016;52:539-556. doi:10.1016/j.tourman.2015.08.010.

38. Kesar O, Rimac K. Medical tourism development in Croatia. Zagreb International Review of Economics and Business. 2011;14(2):107134.

39. Ganguli S, Ebrahim AH. A qualitative analysis of Singapore's medical tourism competitiveness. Tourism Management Perspectives. 2017;21:74-84. doi:10.1016/j.tmp.2016.12.002.

40. Morovati Sharifabadi A, Asadian Ardakani F. A model for health tourism development using Fuzzy TOPSIS and interpretive structural modeling in Yazd province. J Health Adm. 2014;17(55):73-88. [Persian].

41. Nguyen TT. Medical Tourism: Studying the Impact of Motivational Factors, Destination Image on Perceived Quality and Overall Satisfaction using SEM analysis. Pomona: California State Polytechnic University; 2016.

42. Page SJ, Hartwell H, Johns N, Fyall A, Ladkin A, Hemingway A. Case study: wellness, tourism and small business development in a UK coastal resort: Public engagement in practice. Tour Manag. 2017;60:466-477. doi:10.1016/j.tourman.2016.12.014.

43. Khan MJ, Chelliah S, Haron MS, Ahmed S. Role of travel motivations, perceived risks and travel constraints on destination image and visit intention in medical tourism: theoretical model. Sultan Qaboos Univ Med J. 2017;17(1):e11-e17. doi:10.18295/ squmj.2016.17.01.003.

44. Lee M, Han H, Lockyer T. Medical tourism-attracting japanese tourists for medical tourism experience. J Travel Tour Mark. 2012;29(1):69-86. doi:10.1080/10548408.2012.638564.

45. Wang Y-H. Expectation, service quality, satisfaction, and behavioral intention-evidence from taiwan's medical tourism industry. Advances in Management and Applied Economics. 2017;7(1):116.

46. Hadizadeh Moghadam A, Zahedian Nejad MH, Ghanbarzadeh Miyandehi R, Fakharmanesh S. Factors affecting the motivation of medical tourists to enter Iran. J Bus Manag. 2013;12(3):59-79. [Persian].

47. Zailani S, Ali SM, Iranmanesh M, Moghavvemi S, Musa G. Predicting Muslim medical tourists' satisfaction with Malaysian Islamic friendly hospitals. Tour Manag. 2016;57:159-167. doi: 10.1016/j.tourman.2016.05.009.

48. Jabbari A, Delgoshaei B, Mardani R, Tabibi SJ. Medical tourism in Iran: Issues and challenges. J Educ Health Promot. 2012;1:39. doi:10.4103/2277-9531.104809.

49. Johnston R, Crooks VA, Snyder J, Kingsbury P. What is known about the effects of medical tourism in destination and departure countries? A scoping review. Int J Equity Health. 2010;9:24. 
doi:10.1186/1475-9276-9-24.

50. Kelley E. Medical tourism. WTO Patient Safety Programme; 2013.

51. Nasiripour A, Salmani L. The role of Tehran hospital capabilities in the improvement of treatment tourism. Hospital Quarterly. 2010;9(3-4):57-67. [Persian].

52. Khodayari Zarnaq R, Tourani S, Qaderi A, Salehi M, Jafari H. Readiness of teaching hospitals in attracting medical tourists based on joint commission international standards. J Qazvin Univ Med Sci. 2013;17(1):48-54. [Persian].

53. Sitzmann T, Weinhardt JM. Training engagement theory: A multilevel perspective on the effectiveness of work-related training. J Manage. 2015;41(3):1-25. doi:10.1177/0149206315574596.

54. Mintzberg H. Managers, not MBAs: A hard look at the soft practice of managing and management development. San Francisco, CA: Berrett-Koehler Publishers; 2004.

55. Vukovic G, Zavrsnik B, Rodic B, Miglic G. The training of civil servants in the Slovene state administration: issues in introducing training evaluation. Int Rev Adm Sci. 2008;74(4):653-676. doi:10.1177/0020852308098473.

56. Mayaka M, Akama JS. Systems approach to tourism training and education: the Kenyan case study. Tour Manag. 2007;28(1):298306. doi:10.1016/j.tourman.2005.12.023.

57. Somnuek $\mathrm{P}$, ed. The Development of Teaching and Learning Innovation by Using Instructional Media for Enhancement of Learning Achievement towards Tourism Product Knowledge in Tourism Marketing Class. SHS Web of Conferences; 2014. doi:10.1051/shsconf/20141201040

58. Lunt NT, Mannion R, Exworthy M. A framework for exploring the policy implications of UK medical tourism and international patient flows. Soc Policy Adm. 2013;47(1):1-25. doi:10.1111/ j.1467-9515.2011.00833.x.

59. Kazemi Z. Study of the effective factors for attracting medical tourism in Iran. Sweden: Luleå University of Technology; 2008.

60. Taghvaei M, Goodarzi M. Developing and prioritizing the formation of strategies in medical tourism (case study: Shiraz Metropolis). Research and Urban Planning. 2016;7(24):1-22. [Persian].

61. Rahman MK, Zailani S, Ghazali M. What travel motivational factors influence Muslim tourists towards MMITD? J Islam Mark. 2017;8(1):48-73. doi:10.1108/JIMA-05-2015-0030.

62. Ferrer M, Medhekar A. Key operational drivers in the medical tourism industry. International Journal of Accounting Information Science and Leadership. 2012;5(12):62-76.

63. Heidari Chianeh R, Nasrollahzadeh Z, Abdollahi M. An evaluation of tourism higher education in Iran based on SWOT Model. Tourism Planning and Development. 2012;1(1):129-52. [Persian].

64. Sadr Momtaz N, Agharahimi Z. Medical tourism industry in Iran: Strategies for development. Health Information Management. 2011;7(4):516-24. [Persian].

65. Han H. The healthcare hotel: distinctive attributes for international medical travelers. Tour Manag. 2013;36:257-268. doi:10.1016/j. tourman.2012.11.016. 